\title{
Dos casos de muerte debida a sofocación por bolsa de plástico.
}

Two cases of death due to plastic bag suffocation.

E. Barbería Marcalain y cols.

Cuad Med Forense 2004;37:49-56

Se trata de un caso de suicidio en una mujer de 64 años de nacionalidad centroeuropea mediante sofocación por bolsa de plástico. Fue hallada en su domicilio, sobre su cama, tenía la cabeza introducida completamente en una bolsa de plástico de autocierre por tracción, reforzada en torno al cuello por cinta adhesiva transparente (Fig. I). En el examen del lugar de los hechos no se observaron signos de violencia. En el examen externo del cadáver no se observaron signos de lucha o defensa. En el examen interno destacan zonas de sufusión sanguínea en torno a las aponeurosis, en la región próxima a las inserciones mastoideas de ambos músculos esternocleidomastoideo.

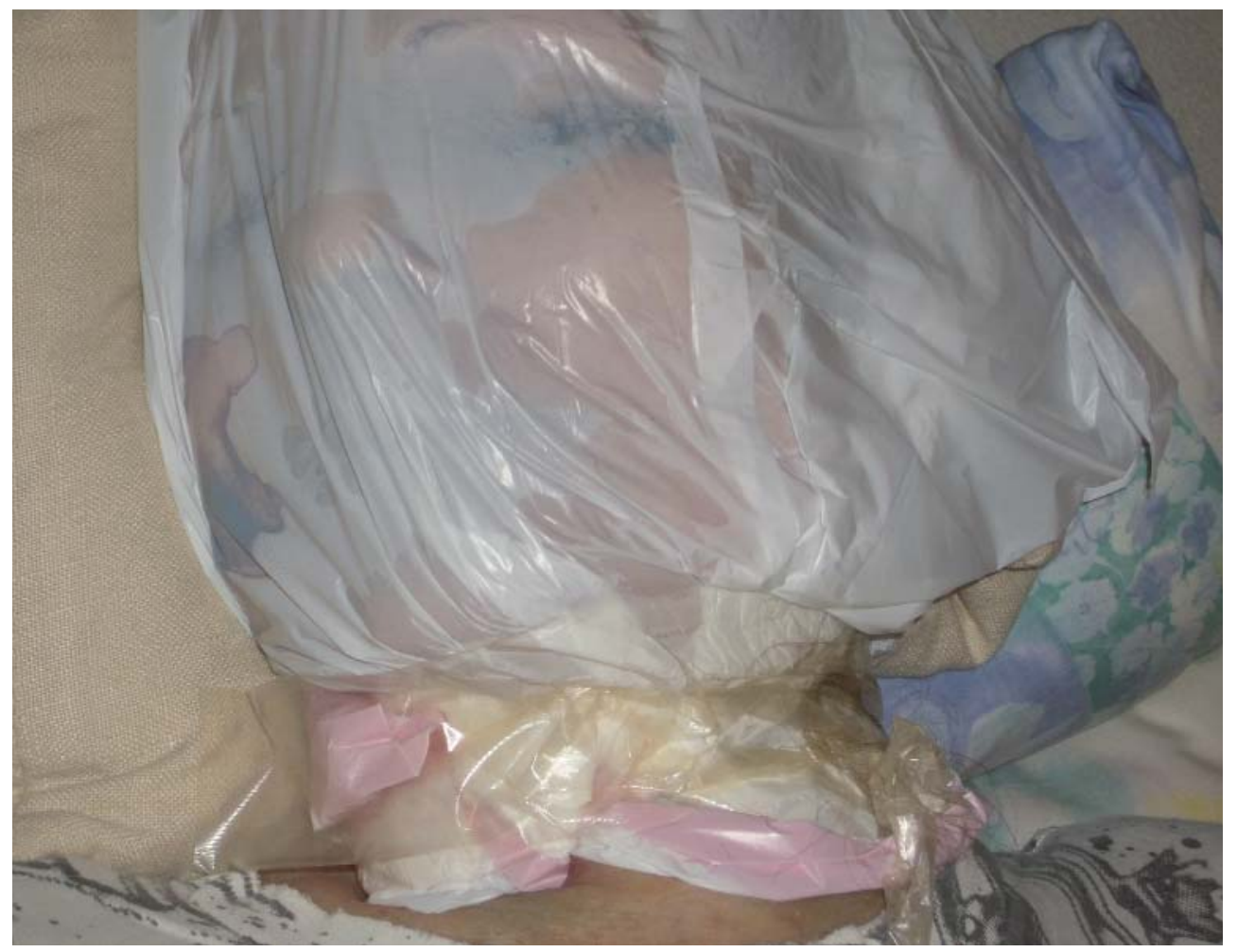

Figura 1.- Características del mecanismo utilizado. Nótese el refuerzo del cierre de la bolsa en torno al cuello. 


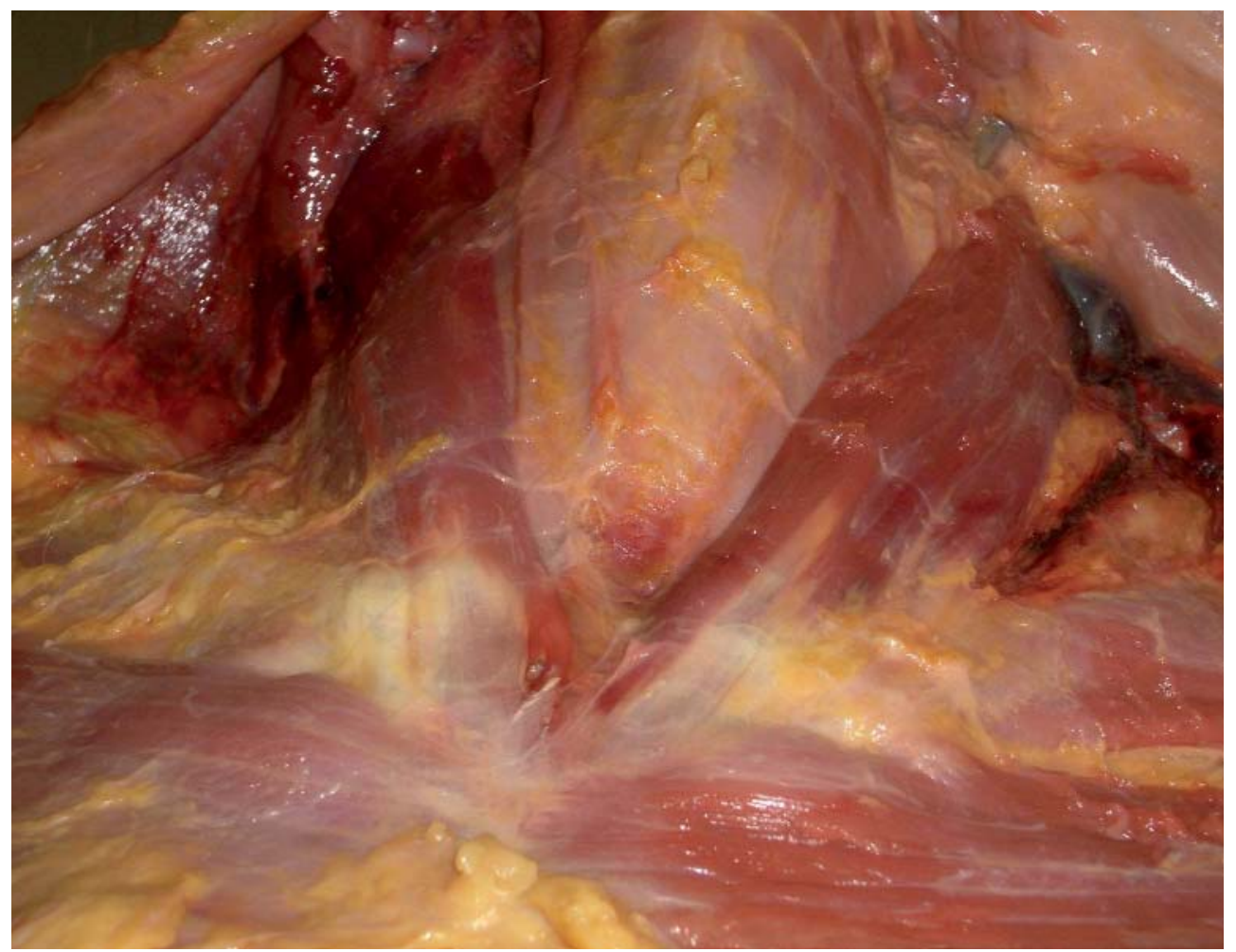

Figura 2.- Signos encontrados en la autopsia del cuello. 